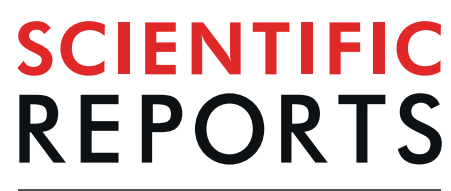

natureresearch

\title{
OPEN Microstructure and chemical composition of Roman orichalcum coins emitted after the monetary reform of Augustus (23 B.C.)
}

Received: 17 April 2019

Accepted: 7 August 2019

Published online: 03 September 2019

\section{Melania Di Fazio ${ }^{1}$, Anna Candida Felici' ${ }^{2}$, Fiorenzo Catalli ${ }^{3} \&$ Caterina De Vito $^{1}$}

A collection of ancient Roman orichalcum coins, i.e., a copper-zinc alloy, minted under the reigns from Caesar to Domitianus, have been characterised using scanning electron microscopy (SEM-EDS) and electron microprobe analysis (EMPA). We studied, for the first time, coins emitted by Romans after the reforms of Augustus (23 B.C.) and Nero (63-64 A.D). These coins, consisting of asses, sestertii, dupondii and semisses, were analysed using non- and invasive analyses, aiming to explore microstructure, corrosive process and to acquire quantitative chemical analysis. The results revealed that the coins are characterized by porous external layers, which are affected by dezincification and decuprification processes. As pictured by the X-ray maps, the elemental distribution of $\mathrm{Cu}$ and $\mathrm{Zn}$ shows patterns of depletion that in some cases penetrate in deep up to $1 \mathrm{~mm}$. The composition of the un-corroded nucleus is a Cu-Zn alloy containing up to $30 \%$ of $\mathrm{Zn}$, typical of coins produced via cementation process.

The term Orichalcum is a classical ancient word used to describe a $\mathrm{Cu}-\mathrm{Zn}$-based alloy with a discrete percentage of $\mathrm{Zn}(5-28 \%)^{1,2}$, and similar in appearance to the modern brass. Higher in value than the bronze, this alloy was melted in the form of ingots ${ }^{3}$ and then used to obtain different kind of objects both in the ancient ${ }^{4-6}$ and modern times ${ }^{7}$.

Orichalcum was rarely used for coinage in the Hellenistic world ${ }^{8}$ and was experimentally used by Romans under the reigns of Caesar and Marcus Antonius.

The scope of the monetary reform of Augustus (23 B.C.) was reducing the disorder of the Republican Roman coinage, introducing sestertii and dupondii in $\mathrm{Cu}-\mathrm{Zn}$ alloy, rather than silver and bronze. Lately, a new monetary reform was made by Nero during the 63-64 A.D., introducing asses, semisses and quadrantes in orichalcum ${ }^{9,10}$.

The cementation process, used to produce the $\mathrm{Cu}-\mathrm{Zn}$ alloy, was improved and developed by ancient Romans for the coinage and production of different kind of artefacts ${ }^{1,2,11,12}$. This process consisted of using crucibles with specific size and shape to reach thermodynamic requirements for orichalcum production. The diffusion of the vapours of zinc into the copper melt produced a $\mathrm{Cu}-\mathrm{Zn}$ based alloy with a maximum content of $\mathrm{Zn}$ near $30 \%$. The maximum content of zinc in orichalcum was mainly controlled by temperature, partial pressure of $\mathrm{Zn}_{\text {vapour }}$ and the redox conditions ${ }^{12}$. The transformation of zinc oxide into metal required (strongly) reducing conditions, with a minimum temperature of about $900^{\circ} \mathrm{C}$. This temperature threshold represents the boiling point of zinc, necessary to produce the vapour phase of $\mathrm{zinc}^{1,13}$. The re-oxidation process and the suitable partial pressure of zinc were provided during cementation process by the use of closed crucibles ${ }^{13,14}$.

Similar processes and techniques of that of Roman cementation were applied and diffused in Middle East ${ }^{5}$, India $^{15}$, China ${ }^{16,17}$, Northern Europe ${ }^{12,13,18}$.

The corrosion of orichalcum coins as well as that of other archaeological artefacts is one of the most important problems linked to the conservation and the preservation of Cultural Heritage materials ${ }^{5-7,19,20}$.

The corrosion of orichalcum is associated with dezincification and decuprification processes ${ }^{21-23}$, which can occur for several microns in depth; therefore, to evaluate the degree of corrosion it is necessary to analyse cross section of samples "from rim-core-to-rim" $24,25$. 
A very limited number of studies about orichalcum coins ${ }^{6,19,21,23}$ and their corrosion are reported and, above all, these contributions are based on the use of qualitative data or semi-quantitative data on dezincification process.

Nowadays, the most common techniques applied to investigate ancient alloys are Scanning Electron Microscope $\mathrm{e}^{6,26,27}$ and X-Ray Fluorescence ${ }^{22,28}$.

A multi-analytical approach ${ }^{29,30}$ based on $\mu$-Raman ${ }^{31}$, X-ray Diffraction, X-ray Photoelectron Spectroscopy ${ }^{32}$ or micro-PIXE ${ }^{33}$ was applied to investigate the external layers of metal object. Electrochemical analysis as Voltammetry of Immobilized Micro Particle and Electrochemical Impedance Spectroscopy ${ }^{34-39}$ are also used to explore the state of conservation of the patina and to identify the corrosion products.

Some authors applied superficial techniques to investigate both corroded and uncorroded alloy composing samples ${ }^{40}$. However, the error related to major and minor elements is too high to help answer to archaeological issues.

Nowadays, the most suitable way to investigate the depth of the dezincification process is to analyse cross sections obtained from samples in study (with the authorisation of the owners of the coins). Destructive analysis should be preferred, when possible, to evaluate the "real" composition of orichalcum, because the small amount of sample removed from the patina of the coins could not be representative of uncorroded alloy ${ }^{2}$. Cross-section analysis allows comparing the real quantity of major elements, which composes orichalcum produced in different age and, thus giving information about the development of the cementation process during the Roman Era.

Recently, EMPA technique was used obtaining quantitative chemical analysis of Roman alloys used for coinage ${ }^{25}$.

The aim of this study is to investigate the composition of the orichalcum coins in the un-corroded nucleus and the corrosion phenomena that affected these coins, acquiring qualitative and quantitative chemical data from the correded external layers to the unaltered core.

We use SEM and EMP analyses to reconstruct the nature of the original alloy and to explore the mechanisms which induced corrosion ${ }^{6}$. The patterns of corrosion are explored using SEM-EDS and X-ray imaging of the elements of the alloy. In addition, a deep investigation of the microstructure is made.

A set of 13 Roman orichalcum coins (Fig. 1 and Table 1) were selected for this study from about 60 coins from Private Collections. Numismatic examination, considering the weight, the size, the legend and the engraved type of each $\operatorname{coin}^{41,42}$, revealed that they are asses, sestertii, dupondii and semisses minted from Julius Caesar to Domitianus. The majority of coins were minted after the two important monetary reform of Augustus (23 B.C.) and Nero (63-64 A.D).

Three samples turned out to be interesting cases of study: the two asses coined by Caligula and Claudius before the introduction of the asses in orichalcum with the Nero reform, and the sestertius coined by Tiberius with a $\mathrm{Cu}$-based alloy, contrary to historical information that describes the Tiberius sestertii as a denomination in orichalcum. Indeed, one of the false certainties of the numismatists is the belief that orichalcum was used by Mithridates VI (120-96 B.C.) for a short time of his coinage ${ }^{8}$, lately experimental emissions by Caesar and Marcus Antonio occur. Finally, under the Julio-Claudian dynasty (from Augustus to Nero), a limited number of denominations (sestertii, dupondii and under Nero also semisses and quadrantes) ${ }^{43}$ were emitted in orichalcum.

This research attempts to fill the scientific gap existing in the Roman orichalcum coinage, contributing to characterize this ancient alloy, to better understand the dezincification process and to highlight possible differences among samples minted in different years.

\section{Results and Discussion}

XRF investigation for a preliminary discrimination of the coins. A preliminary XRF analysìs allows confirming that the majority of the samples are in orichalcum; although those affected by important dezincification process can be erroneously consider Cu-based alloys. This investigation is useful to test the presence of $\mathrm{Zn}$ in the surfaces even at low percentage, avoiding unnecessary cutting of the samples that are not in orichalcum. Indeed, deep corroded orichalcum coins are similar in appearance to that in bronze alloy.

Despite numismatic references, the screening by XRF on a non-orichalcum sestertius, minted under Tiberius, revealed the presence of zinc (sample 6\#, RIC I, 248 var.). In addition, two asses, theoretically in bronze and minted during Caligula and Claudius Empires, seemed also to be composed of orichalcum (sample C9, RIC I, 2 Caligula 35, sample A9, RIC I, 248$)^{42}$.

The surface analysis by XRF reveals the presence of $\mathrm{Cu}$ and $\mathrm{Zn}$ as two main alloy components, followed by $\mathrm{Fe}$ and $\mathrm{Pb}$. Tin is present in all samples, with higher peaks particularly in A2, A and B14 samples than others. Chlorine occurs in all samples (Fig. 1S), but in low amounts as highlighted by the low-intensity of its characteristic peaks. Exogenous elements, such as $\mathrm{Ca}, \mathrm{S}, \mathrm{Si}, \mathrm{Al}, \mathrm{P}$ and $\mathrm{Mn}$ are also present ${ }^{19}$ and represent contaminants from soils through porosity of the external layer.

SEM investigation of the microstructure, qualitative chemical composition and elemental distribution. The results on cross-sections analyses of all the coins allow studying microstructure and compositional variations along the thickness of the coins. The microstructure of the alloy presents (SE image at high magnification) the typical $\alpha$ grains structure, clearly visible near the external rim of the sample A3 (Fig. 2b). This is the result of an efficient casting-cooling practice, suggesting a well-controlled cementation process ${ }^{44}$. The grains size varies from $\sim 50 \mu \mathrm{m}$ to $\sim 300 \mu \mathrm{m}$, suggesting a non-rapid cooling speed. Moreover, some grains present deformed borders with thin strain lines inside (Fig. 2a, sample B4 and Fig. 2b, sample A3), due to heavy cold-working, which causes of the slip of crystal planes with the result of a series of parallel movements that produced fine lines ${ }^{44,45}$. In addition, the twin lines do not present further deformation, suggesting that coins were struck only once. The dendritic structures are not observed. 

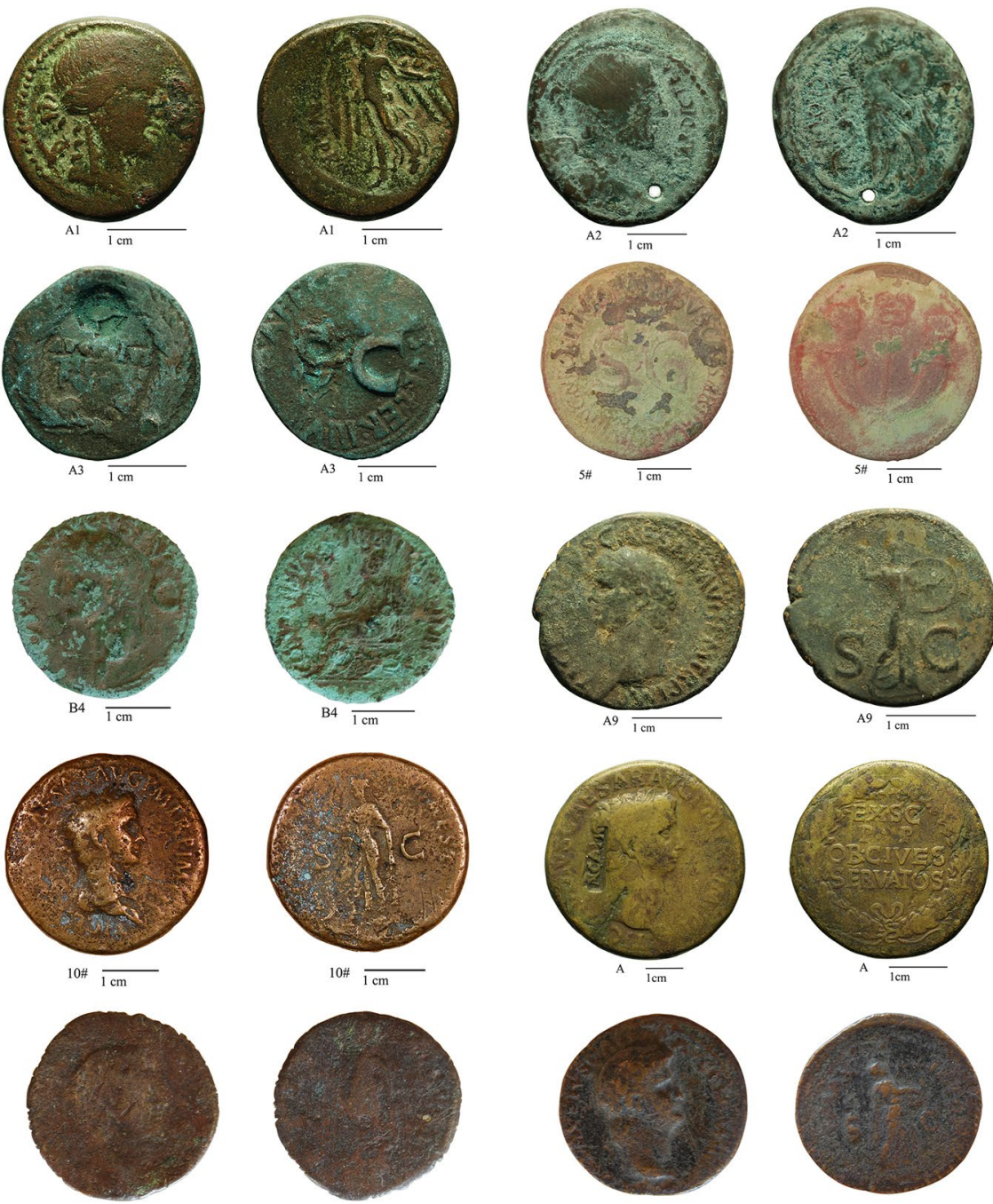

B5 $1 \mathrm{~cm}$

B5 $1 \mathrm{~cm}$

B14 $\overline{1 \mathrm{~cm}}$

B14 $\overline{1 \mathrm{~cm}}$
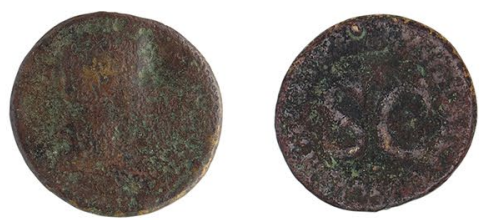

C9 $\overline{1 \mathrm{~cm}}$
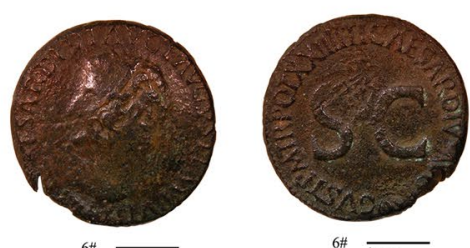

$6 \# \frac{}{1 \mathrm{~cm}}$

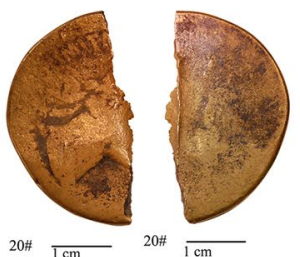

Figure 1. The orichalcum coins studied in this work. Numismatic information is reported in Table 1.

We present and discuss here the results of samples 5\# and B14 (Fig. 2c,d) from the external corroded layers to the inner core, having high and low degree of corrosion, respectively. In addition, the chemical composition of the unaltered area gives information about the ratio of the two main metals in the alloy.

The corroded patina has an irregular thickness with different degree of dezincification, followed by high porosity in the external areas. Sample B14 (Fig. 2d) has two different layers of patina, i.e., the external one (darker grey) has a thickness of few microns with partial detachments from the sample; the second layer (medium grey) is more coherent with the un-corroded core (lighter grey). On the contrary, the patina of the sample 5\# (Fig. 2c) has one layer with an irregular surface in shape. In this sample an important dezincification process occurs, extending up to $1.2 \mathrm{~mm}$ in depth. The corrosion proceeds from the rim to the inner core with micro-areas of selective 


\begin{tabular}{|c|c|c|c|c|c|c|}
\hline Sample & $\begin{array}{l}\text { Value } \\
\text { (denomination) }\end{array}$ & Authorithy & Emission authority & year & Mint & Numismatic reference \\
\hline A1 & As & - & Q. Oppius & 88 B.C. & Laodicea (Turkey) & RRC 550/1-2 \\
\hline A2 & As & G. Iulius Caesar (100 B.C.-44 B.C.) & C. Clovius & 45 B.C. & Uncertain & RRC 476/1-2 \\
\hline A3 & Dupondius & Augustus (63 B.C. -14 A.D.) & C. Cassius Celer & 16 B.C. & Rome & RIC I, 2 Augustus 375 \\
\hline $5 \#$ & Sestertius & Tiberius (42 B.C.-37 A.D.) & - & 22-23 A.D. & Rome & RIC I, 2 Tiberius 42 \\
\hline 6\# & Sestertius & Tiberius (42 B.C.-37 A.D.) & - & $21-22$ & Rome & RIC I, 2 Tiberius 48 var. \\
\hline B4 & Dupondius & Caligula (12-41 A.D.) & - & 37-41 A.D. & Rome & RIC I, 2 Gaius/Caligula 56 \\
\hline C9 & As & Caligula (12-41 A.D.) & - & 37-38 A.D. & Rome & RIC I, 2 Gaius/Caligula 35 \\
\hline A9 & As & Claudius (10-54 A.D.) & - & 41-50 A.D. & Rome & RIC I, 2 Claudius 100 \\
\hline $10 \#$ & Sestertius & Claudius (10-54 A.D.) & - & 41-50 A.D. & Rome & RIC I, 2 Claudius 99 (?) \\
\hline A & Sestertius & Claudius (10-54 A.D.) & & 50-54 A.D. & Rome & RIC I, 2 Claudius 112 \\
\hline B5 & Sestertius & Claudius (10-54 A.D.) & - & 50-54 A.D. & Rome & RIC I, 2 Claudius 115 \\
\hline $\mathrm{B} 14$ & Semis & Nero (37-68 A.D.) & - & 62-68 A.D. & Rome & RIC I, 2 Nero 78 \\
\hline $20 \#$ & Sestertius & Domitianus (51-96 A.D.) & - & - & - & - \\
\hline
\end{tabular}

Table 1. Numismatic features of the coins. Samples 6\#, C9 and A9 are considered exotic samples.
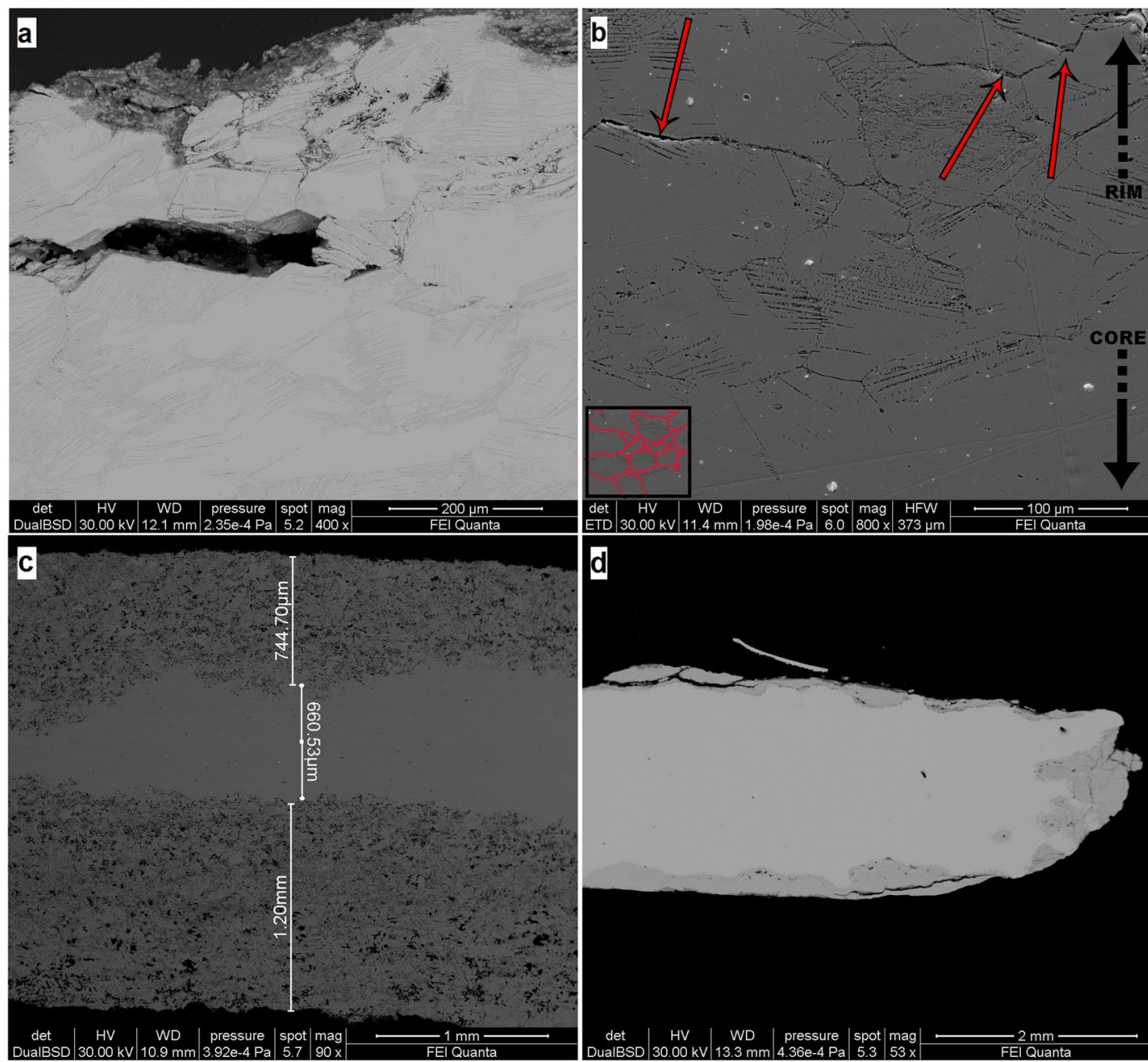

Figure 2. BSE images of coins B4(a), 5\#(c) and B14(d) and SE image of coin A3(b). The $\alpha$-grains structure and the strain lines are evident in (a) and (b). The process of dezincification is showed in (c) and (d), reaching $1.2 \mathrm{~mm}$ as the maximum depth of corrosion (c). The red arrows in (b) indicate the trans-granular stress corrosion.

corrosion (Fig. 3, BSE image), driven by grain boundaries of the $\alpha$-grain structure ${ }^{6}$ of the alloy. This selective corrosion is evident in sample 5\# (Fig. 3), where the content of $\mathrm{Zn}$ in corroded micro-domains (darker grey) is below the 20\%; whereas in the lighter grey micro-domains $\mathrm{Zn}$ content is similar to that of un-corroded nucleus 

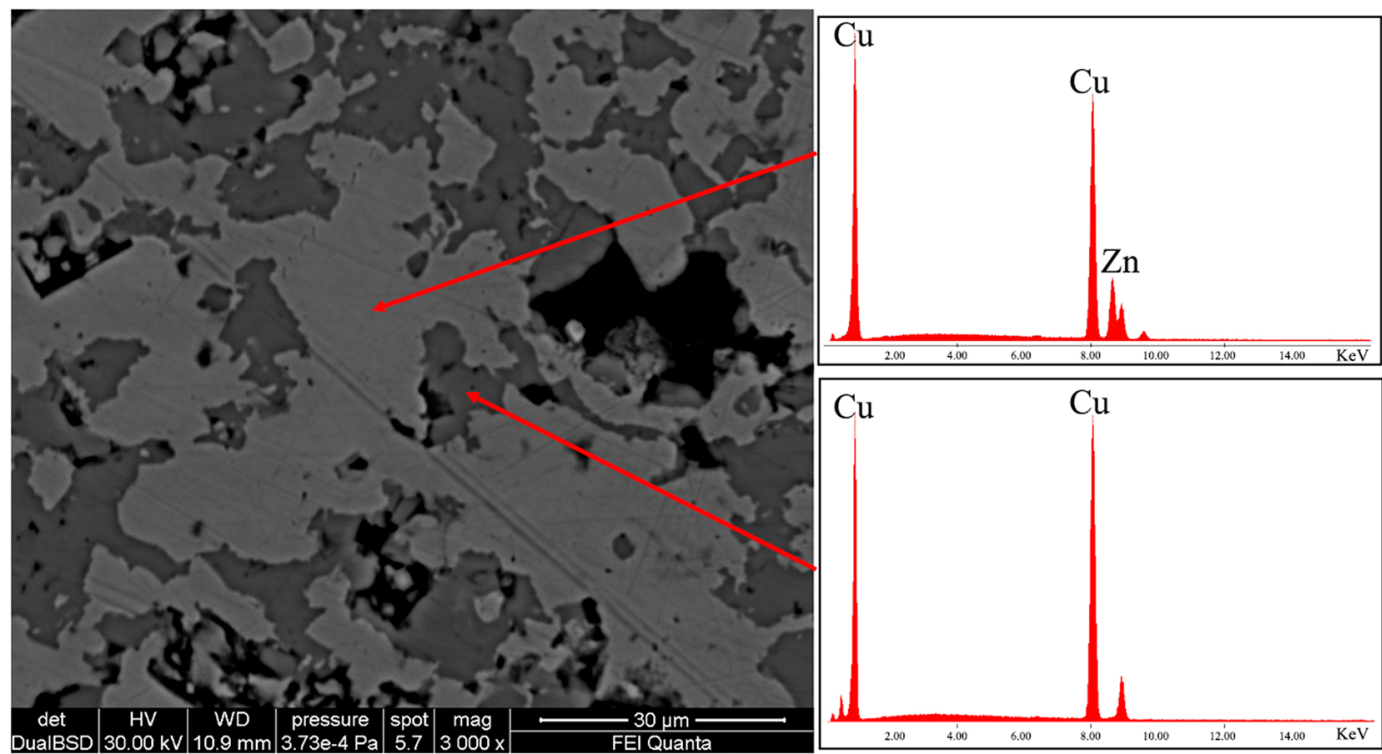

Figure 3. BSE image of the external patina of sample 5\# in cross section. ESD spectrum acquired on the lighter area shows a $\mathrm{Cu}-\mathrm{Zn}$ alloy and that of the darker areas shows only $\mathrm{Cu}$, due to the loss of $\mathrm{Zn}$.

\begin{tabular}{|l|l|l|l|l|l|l|}
\hline \multirow{2}{*}{$\begin{array}{l}\text { Element } \\
\text { (w.t. \%) }\end{array}$} & \multicolumn{2}{|l|}{ Upper corroded layer } & \multicolumn{2}{l|}{ Un-corroded core } & \multicolumn{2}{l|}{ Lower corroded layer } \\
\cline { 2 - 7 } & Darker grey & Lighter grey & $\begin{array}{l}\text { Upper } \\
\text { point }\end{array}$ & $\begin{array}{l}\text { Lower } \\
\text { point }\end{array}$ & Darker grey & Lighter grey \\
\hline $\mathrm{Cu}$ & 91.78 & 86.41 & 77.17 & 77.28 & 99.05 & 93.63 \\
\hline $\mathrm{Zn}$ & 6.98 & 12.42 & 23.49 & 23.38 & 0.60 & 5.42 \\
\hline
\end{tabular}

Table 2. Quantitative EMP analyses of major element of the sample 5\#. Data of darker and lighter grey areas are referred to BSE image of Fig. 4.

(Table 2). The selective dealloying can be attribute to the trans-granular stress corrosion, usually observed in alloys with content of $\mathrm{Zn}$ between $20 \%$ and $30 \%{ }^{46}$ and can be clearly observed at the contact of the border zones of the sample A3 (Fig. 2b, red arrows). With the evolution of the dezincification process in the external layer is formed a sponge-type structure, typical of brass with low content of Sn, as observed by Constantinides et al. ${ }^{47}$ in standard sample representative of archaeological brass. Moreover, in the most corroded areas of this layer porous microstructure was found as reported also in previous studies ${ }^{21,48}$ mainly made by copper oxides.

In addition, qualitative EDS analysis (Fig. 3, EDS spectra) were carried out to evaluate the chemical composition of the unaltered core of the coins. EDS spectra confirmed that $\mathrm{Cu}$ and $\mathrm{Zn}$ are the two major elements composing the alloy. Lead is present in samples A1, A2, B5 and 20\#, whereas Sn in samples A3, 20\#, occurring these elements as minor and/or trace. Iron occurs in A1, A2, A, B4, 5\#, 20\#.

$\mathrm{X}$-ray maps of the elements composing the alloy provide information about their distribution along rim-core-rim cross-sections. The maps of samples 5\# and B5 (Figs 4 and 5) illustrate two different degrees of dezincification, revealed studying the whole coin set: a high level of corrosion, for example in sample \#5 (Fig. 4) and a medium level of corrosion, as in sample B5 (Fig. 5). The core of almost all the samples, as shown in the $\mathrm{X}$-ray maps (Fig. 4 and Fig. 5), presents a homogeneous distribution of $\mathrm{Cu}, \mathrm{Zn}$ and, where present, also of Sn. These patterns indicate an expertise in cementation process by Romans and a well-controlled procedure during the melting-cooling phase of the alloys in the Roman mint, with a diffusion of $\mathrm{Zn}$ at nanoscale level along with the absence of micro-domains of $\mathrm{Cu}$ and $\mathrm{Zn}$. Lead, when present in the alloy, forms droplets of different size throughout the coin, due to the low solubility of these two metallic elements, which at low temperature do not give solid solution ${ }^{18}$. The homogeneous presence of Fe (Fig. 4) suggests the use of chalcopyrite rich-ore for the extraction of $\mathrm{Cu}$. However, the superficial Fe-enrichment can be explained with the contribution of exogenous $\mathrm{Fe}$ from the soils. The occurrence of $\mathrm{Pb}$ suggests the use of raw materials composed of a mix of base-metals, such as chalcopyrite, galena and sphalerite or the use of calamine from carbonate-hosted $\mathrm{Zn}(\mathrm{Pb})$ ore deposits ${ }^{49}$. As previously revealed by XRF analyses, the occurrence of exogenous $\mathrm{Cl}$ probably induced corrosion processes, producing pitting on the surface of the coins, due to the high pitting potential of the $\mathrm{Cu}-\mathrm{Zn}$ alloy attributed to the presence of $\mathrm{Cu}_{2} \mathrm{O}$ and $\mathrm{ZnO}$ on the coins' patina ${ }^{50}$.

The rim of the coins, as showed in the X-ray maps (Figs 4 and 5), presents evidence of dezincification process, involving $\mathrm{Cu}$ enrichment in the external surfaces.

SEM investigation of the exotic samples. The three exotic samples, asses C9, asses A9 and sestertius 6\#, were also investigated using SEM technique. 


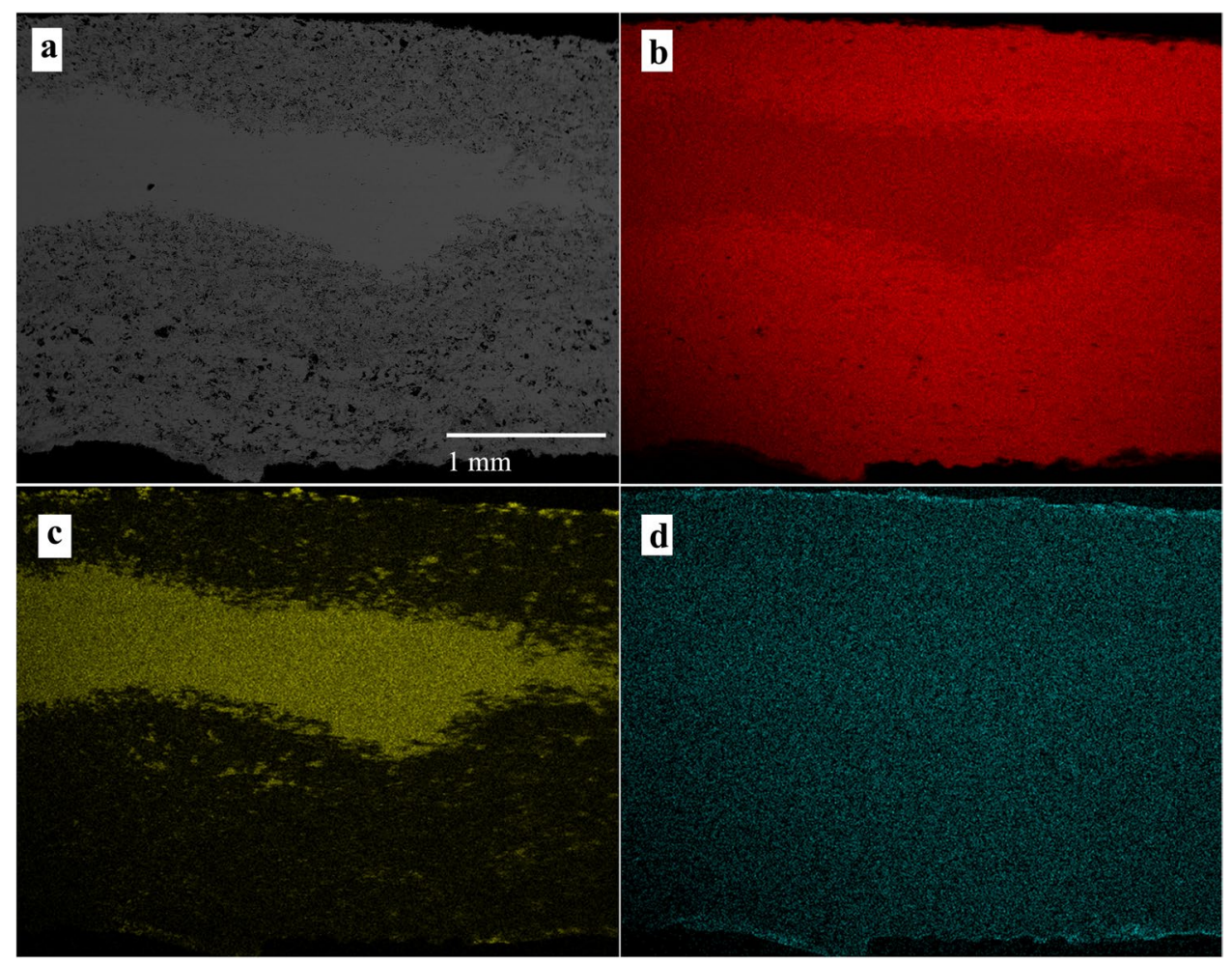

Figure 4. BSE image of sample 5\# (a) and X-ray maps of $\mathrm{Cu}(\mathbf{b}), \mathrm{Zn}(\mathbf{c})$ and $\mathrm{Fe}(\mathbf{d})$.

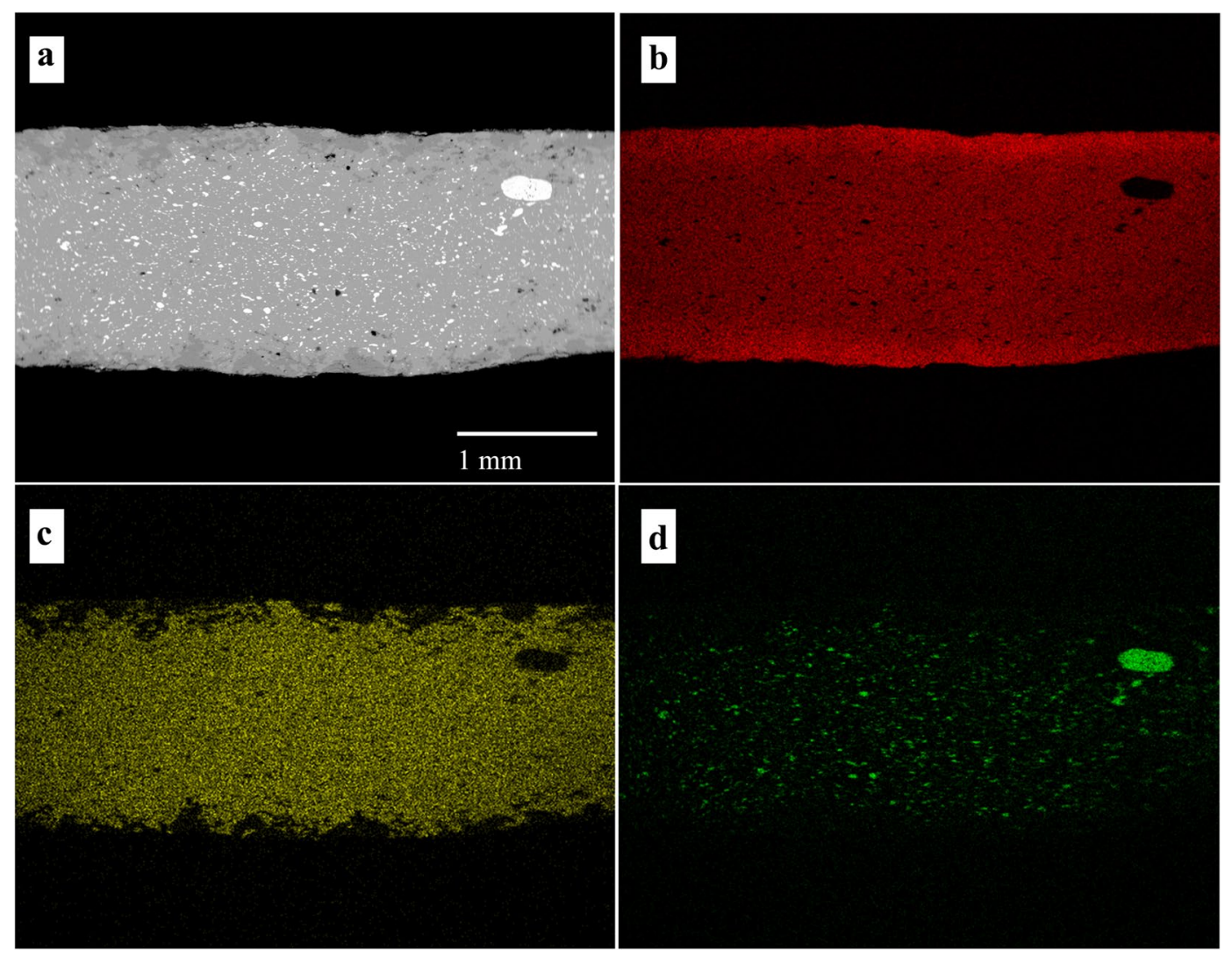

Figure 5. BSE image of sample B5 (a) and X-ray maps of $\mathrm{Cu}(\mathbf{b}), \mathrm{Zn}(\mathbf{c})$ and $\mathrm{Pb}(\mathbf{d})$. 


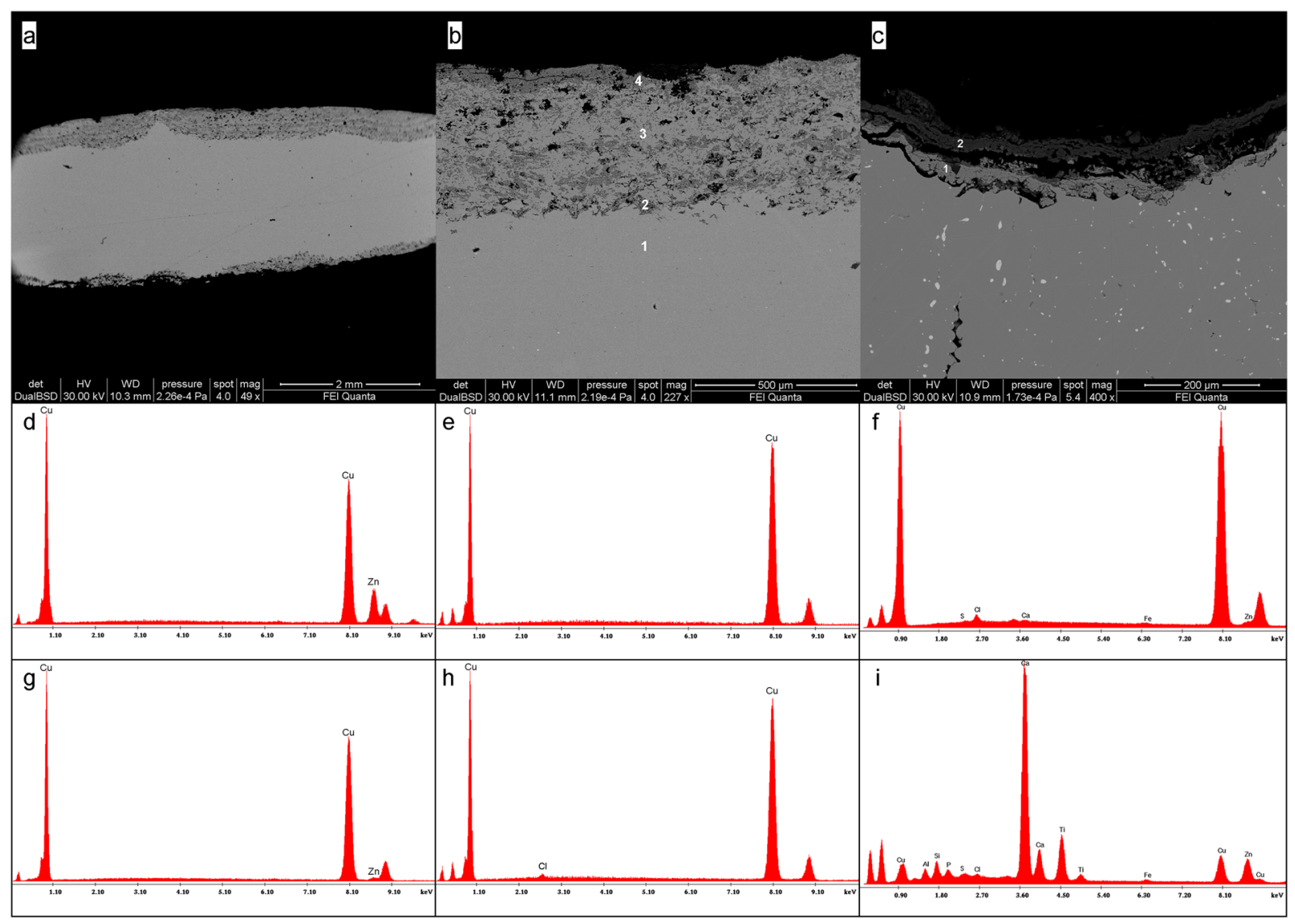

Figure 6. BSE images of exotic samples C9 (a,b) and A9 (c). The EDS spectra of sample C9 in points 1, 2, 3 and $4(\mathbf{d}-\mathbf{h})$ were acquired in spot analyses as highlighted in (b). The EDS spectra of sample A9 were acquired in points 1 and $2(\mathbf{f}, \mathbf{i})$ as highlighted in $(\mathbf{c})$.

As other orichalcum samples, C9 presents a corroded patina extended up to $\sim 400 \mu \mathrm{m}$ in depth, with a medium degree of porosity (Fig. 6a). Also in this case, the corroded area is characterized by micro-domains with different amount of $\mathrm{Zn}$, due to a selective de-alloying. However, the distribution of the corroded micro-domains follows a banded structure (Fig. 6a,b) in which high dezinced areas (darker grey) are alternated to low dezincificated areas (lighter grey). Qualitative EDS analysis confirms the presence of the corroded bands if compared to the one of the uncorroded area. Indeed, the unaltered alloy presents the typical $\mathrm{Cu}-\mathrm{Zn}$ composition of the orichalcum (Fig. 6d, EDS spectrum corresponding to point 1 in Fig. 6b), whereas the corroded bands are Zn depleted (Fig. 6e, h EDS spectra corresponding respectively to points 2 and 4 in Fig. 6b) and the bands with a low degree of dezincification (Fig. 6b, point 3) present an intermediate composition between the unaltered alloy and the corroded areas (Fig. $6 \mathrm{~g}$ EDS spectrum).

Sample A9 presents a remarkable detachment of the patina from the sample (Fig. 6c). The patina is composed of two different layers, where the external one presents a higher degree of corrosion than the inner layer. EDS analysis shows the presence of exogenous elements, such as $\mathrm{C}, \mathrm{O}, \mathrm{Al}, \mathrm{Si}, \mathrm{Ca}, \mathrm{P}, \mathrm{S}, \mathrm{Ti}$ and $\mathrm{Fe}$ as contaminants from soils, on the external surface and inside the empty space derived from the detachment of the patina (Fig. 6i, EDS spectrum corresponding to point 2 in Fig. 6c). The presence of Zn showed by EDS spectrum of the inner layer (Fig. 6f, EDS spectrum corresponding to point 1 in Fig. 6c) suggests a lower degree of corrosion, and a less presence of contaminants elements, probably due to the protective effect induced by the outer passive layer.

Also $\mathrm{Cl}$ occurs in both the corroded layers of the patina (Fig. 6f,i), inducing the corrosion process and in turn the detachment of the layers from the sample.

Sample 6\# is one of the two sestertii minted during the reign of Tiberius here studied (the other one is sample 5\#). The alloy of this sample is a Cu-Sn-based alloy (bronze), contrary to the rules of the monetary reform of Augustus (23 B.C.), and presents a homogeneous pattern through the section (rim-core-rim analysis with SEM-EDS). The $\mathrm{Cu}$ depleted patina is extended up to $\sim 120 \mu \mathrm{m}$ in depth and results particularly corroded in the intergranular zone. Chlorine is present in the areas where $\mathrm{Cu}$ depletion occurs, and an high porosity characterizes the patina.

EMP analysis of the un-corroded nucleus. EMP analysis of the un-corroded nucleus allows obtaining quantitative chemical compositions of the coins and along with SEM imaging and X-ray maps permits to reconstruct the dezincification and decuprification pattern through the section (rim-core-to-rim). This analysis was necessary to determinate the composition of the orichalcum alloy without the influence of the corroded external surfaces and to highlight differences among alloys casted under different Emperors. 
a

Comparison between sample $5 \#$ and sample $A$

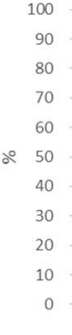

C

100.00

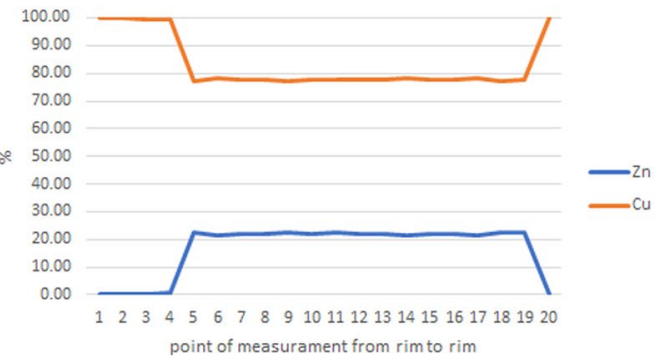

b

Trend of minor and trace elements in sample B5

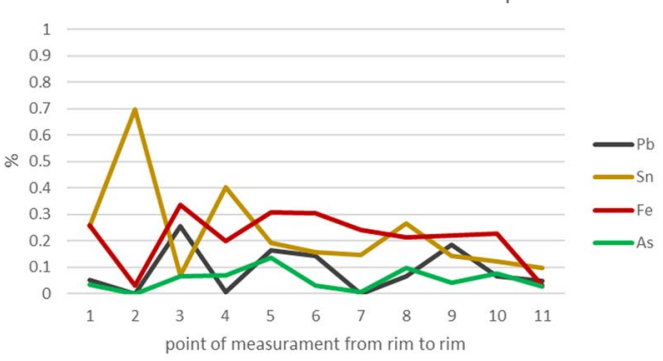

d

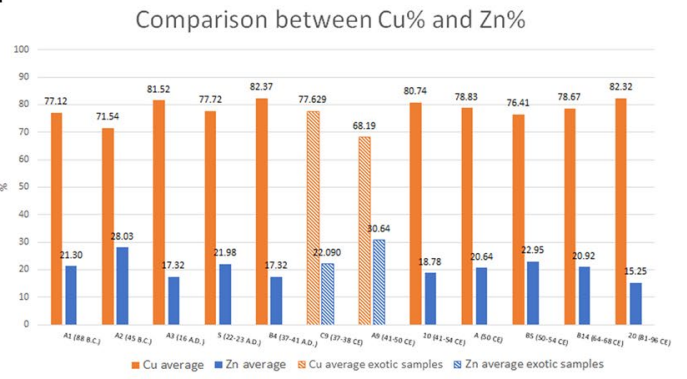

Figure 7. Patterns of EMP analysis on cross section and chronological comparison among samples. (a) The line-graph represent the comparison between the pattern of $\mathrm{Cu}$ and $\mathrm{Zn}$ in samples 5\# and $\mathrm{A}$. Dashed lines describe the area of the uncorroded core of sample 5\#; (b) line-graph representing the trend of minor and trace elements ( $\mathrm{Pb}, \mathrm{Sn}, \mathrm{Fe}$ and $\mathrm{As}$ ) in sample B5; (c) line-graph representing the trend of $\mathrm{Cu}$ and $\mathrm{Zn}$ in sample $\mathrm{C}$; (d) bar-plot of chronological comparison of the average of major elements in orichalcum coins. The bars with a line pattern represent the average $\mathrm{Cu}$ or $\mathrm{Zn}$ values of the exotic samples. Data were obtained considering the uncorroded core of each sample, using a minimum of 8 to 22 spot analyses.

Samples with low degree of corrosion show homogeneous distribution of $\mathrm{Cu} \%$ and $\mathrm{Zn} \%$ throughout the section (i.e., sample A), whereas in the corroded samples the percentage of $\mathrm{Zn}$ varies from $1.33 \%$ to $23.49 \%$ (sample 5\#, Fig. 7a). The exotic coin C9 presents trend of values of the two main elements, from one rim to the other, comparable to samples with high degree of corrosion (Fig. 7c). Indeed, the first 4 point of measurements $(400 \mu \mathrm{m} \mathrm{ca}$.) have $98-99 \%$ of $\mathrm{Cu}$ and values of $\mathrm{Zn}<0.5 \%$. This confirms the high degree of dezincification of the sample. In the uncorroded core of the coin, the alloy is composed mainly of $77 \% \mathrm{ca}$. of $\mathrm{Cu}$ and $20 \% \mathrm{ca}$. of $\mathrm{Zn}$, whereas in the last $100 \mu \mathrm{m}$ of the cross section the values of the major elements return to having the values of the other side patina. The exotic coin A9 does not presents compositional variation of $\mathrm{Cu}$ and $\mathrm{Zn}$ in the whole section, confirming the low degree of corrosion of such sample. Moreover, A9 is composed of the alloy with the maximum average value of $\mathrm{Zn}(30.64 \%)$ of the whole collection.

Minor and trace elements such as $\mathrm{Sn}$, As and $\mathrm{Fe}$, present homogenous values in un-corroded areas of the alloy (Fig. 7b), whereas $\mathrm{Pb}$ is often heterogeneous as in some samples it occurs as exsolution domains from $\sim 400 \mu \mathrm{m}$ to $\sim 5 \mu \mathrm{m}$ resulting in $\mathrm{Pb}$-rich areas (Fig. 5). The low content of Fe and their trend from rim to rim inside the samples can suggest the use of chalcopyrite to extract $\mathrm{Cu}$ (Table 3 ).

EMPA data acquired in the uncorroded core of each coin are compared with the average values of Caley ${ }^{51}$, from this comparison our data show an irregular fluctuation of $\mathrm{Cu}$ and $\mathrm{Zn}$ through 100 years of minting of orichalcum coins (Fig. 7d). Therefore, the fluctuations of $\mathrm{Cu}$ and $\mathrm{Zn}$ seem to suggest difficulties in the supply of raw materials as well as not regular control of the cementation process to produce orichalcum ingots.

Previous studies ${ }^{51}$ suggested the possibility to approximately date coins, and other orichalcum objects, comparing the content of $\mathrm{Zn}$ in the alloy with that of a series of dated coins. Caley described a decrease of the $\mathrm{Zn}$ that corresponded to a regular increase in the average proportion of $\mathrm{Sn}$ and $\mathrm{Pb}$, from the oldest to the most recent coins (23 B.C. - 162 A.D.). He justified the chronological decrease of the $\mathrm{Zn}$ with the necessity of recasting of metals. However, comparing the private collection analysed in the present study with the results of Caley ${ }^{51}$, the chronology by $\mathrm{Cu}$ and $\mathrm{Zn}$ percentages results different. Indeed, the average value of $\mathrm{Zn}$, from 88 B.C. to 96 A.D., results extremely variable and fluctuating (Fig. $7 \mathrm{~d}$ ), exceeding sometimes the value of $28 \%$ considered as the maximum limit possible in ancient brasses by some authors ${ }^{44}$.

\section{Methods}

All the information on samples, concerning year and place of coinage, emission authority and numismatic references, is reported in Table 1 .

Preliminarily, qualitative elemental analyses on the patinas were carried out by energy-dispersive X-ray fluorescence spectroscopy (EDXRF) (Department of Basic and Applied Sciences for Engineering, Sapienza University of Rome, Italy). The spectrometer consists of an X-ray generator (Amptek MiniX) with an anode target of rhodium and a beryllium window of $127 \mu \mathrm{m}$ of thickness. The detector is a Peltier cooled silicon drift with integrated 


\begin{tabular}{|c|c|c|c|c|c|c|c|c|c|c|c|c|c|c|c|c|c|c|}
\hline \multirow[b]{2}{*}{ Element (w.t.\%) } & \multicolumn{3}{|l|}{ A1 } & \multicolumn{3}{|l|}{ A2 } & \multicolumn{3}{|l|}{ A3 } & \multicolumn{3}{|l|}{$5 \#$} & \multicolumn{3}{|l|}{ B4 } & \multicolumn{3}{|l|}{ C9 } \\
\hline & Max. & Min. & $\begin{array}{l}\text { Avg. } \\
n=13\end{array}$ & Max. & Min. & $\begin{array}{l}\text { Avg. } \\
n=15\end{array}$ & Max. & Min. & $\begin{array}{l}\text { Avg. } \\
n=10\end{array}$ & Max. & Min. & $\begin{array}{l}\text { Avg. } \\
\mathrm{n}=8\end{array}$ & Max. & Min. & $\begin{array}{l}\text { Avg. } \\
\mathrm{n}=8\end{array}$ & Max. & Min. & $\begin{array}{l}\text { Avg. } \\
\mathrm{n}=15\end{array}$ \\
\hline $\mathrm{Cu}$ & 79.42 & 72.52 & 77.12 & 72.01 & \begin{tabular}{|l|}
71.27 \\
\end{tabular} & 71.54 & 82.12 & 81.14 & 81.52 & 85.30 & 76.21 & 77.72 & 82.87 & 82.05 & 82.37 & 78.30 & \begin{tabular}{|l|}
77.12 \\
\end{tabular} & 77.63 \\
\hline $\mathrm{Zn}$ & 22.34 & 19.75 & 21.30 & 28.28 & 27.59 & 28.03 & 17.82 & 16.73 & 17.32 & 23.49 & 14.46 & 21.98 & 17.65 & 16.89 & 17.32 & 22.56 & 21.40 & 22.09 \\
\hline $\mathrm{Pb}$ & 5.49 & 0.00 & 0.45 & 0.20 & 0.00 & 0.06 & 0.09 & 0.00 & 0.03 & \begin{tabular}{|l|}
0.09 \\
\end{tabular} & 0.00 & 0.03 & 0.11 & 0.00 & 0.04 & \begin{tabular}{|l|}
0.07 \\
\end{tabular} & 0.00 & \begin{tabular}{|l|}
0.02 \\
\end{tabular} \\
\hline $\mathrm{Fe}$ & 0.47 & 0.21 & 0.32 & 0.29 & 0.19 & 0.24 & 0.40 & 0.25 & 0.34 & 0.17 & 0.03 & 0.13 & 0.11 & 0.03 & 0.07 & 0.21 & 0.12 & 0.18 \\
\hline $\mathrm{Sn}$ & 1.14 & 0.35 & 0.73 & 0.09 & 0.00 & 0.06 & 0.84 & 0.61 & 0.72 & 0.13 & 0.04 & 0.09 & 0.18 & 0.09 & 0.02 & 0.11 & 0.00 & 0.02 \\
\hline \multirow[t]{2}{*}{ As } & 0.09 & 0.00 & 0.03 & 0.09 & 0.00 & 0.04 & 0.04 & 0.00 & 0.01 & 0.06 & 0.00 & 0.02 & 0.10 & 0.00 & 0.05 & 0.06 & 0.00 & 0.02 \\
\hline & \multicolumn{3}{|l|}{ A9 } & \multicolumn{3}{|l|}{$10 \#$} & \multicolumn{3}{|l|}{ A } & \multicolumn{3}{|l|}{ B5 } & \multicolumn{3}{|l|}{ B14 } & \multicolumn{3}{|l|}{$20 \#$} \\
\hline Element (w.t.\%) & Max. & Min. & $\begin{array}{l}\text { Avg. } \\
n=18\end{array}$ & Max. & Min. & $\begin{array}{l}\text { Avg. } \\
n=14\end{array}$ & Max. & Min. & \begin{tabular}{|l} 
Avg. \\
$n=22$
\end{tabular} & Max. & Min. & $\begin{array}{l}\text { Avg. } \\
\mathrm{n}=\mathbf{8}\end{array}$ & Max. & Min. & $\begin{array}{l}\text { Avg. } \\
\mathrm{n}=\mathbf{9}\end{array}$ & Max. & Min. & $\begin{array}{l}\text { Avg. } \\
\mathrm{n}=11\end{array}$ \\
\hline $\mathrm{Cu}$ & 69.75 & 67.61 & 68.19 & 81.19 & 80.22 & 80.74 & 81.01 & 77.72 & 78.83 & 76.98 & 75.55 & 76.41 & 79.00 & 78.44 & 78.67 & 83.47 & 81.99 & 82.32 \\
\hline $\mathrm{Zn}$ & 31.25 & 29.29 & 30.64 & 19.03 & 18.45 & 18.78 & 21.68 & 18.38 & 20.64 & 23.73 & 22.40 & 22.95 & 21.41 & 20.65 & 20.92 & 15.02 & 15.41 & 15.25 \\
\hline $\mathrm{Pb}$ & 0.10 & 0.00 & 0.02 & 0.77 & 0.00 & 0.12 & 0.17 & 0.00 & 0.06 & 0.25 & 0.00 & 0.11 & 0.10 & 0.00 & 0.03 & 0.06 & 0.00 & 0.03 \\
\hline $\mathrm{Fe}$ & 0.05 & 0.00 & 0.01 & 0.24 & 0.17 & 0.21 & 0.38 & 0.27 & 0.34 & 0.34 & 0.20 & 0.25 & 0.31 & 0.20 & 0.24 & 0.32 & 0.34 & 0.28 \\
\hline $\mathrm{Sn}$ & 1.36 & 0.68 & 1.08 & 0.13 & 0.02 & 0.06 & 0.15 & 0.01 & 0.07 & 0.40 & 0.07 & 0.19 & 0.07 & 0.00 & 0.04 & 2.27 & 1.00 & 2.03 \\
\hline As & 0.10 & 0.00 & 0.01 & 0.10 & 0.02 & 0.06 & 0.05 & 0.00 & 0.01 & 0.13 & 0.01 & 0.06 & 0.15 & 0.00 & 0.07 & 0.05 & 0.00 & 0.01 \\
\hline
\end{tabular}

Table 3. Maximum (Max.), minimum (Min.) and average (Avg.) EMP analyses of major, minor and trace elements.

amplifier and multi-channel analyzer (Amptek 123-SDD). The detector has a surface of $25 \mathrm{~mm}^{2}$, a thickness of $450 \mu \mathrm{m}$, a beryllium window of $12.5 \mu \mathrm{m}$ of thickness and its energy resolution is $140 \mathrm{eV}$, full width half maximum at $5.9 \mathrm{keV}$. The incident and the revealed beams form an angle of $45^{\circ}$ with respect to the surface of the sample. The analysed surface is distant $3 \mathrm{~cm}$ from the X-ray generator anode and $3.5 \mathrm{~cm}$ from the detector surface. The $\mathrm{X}$-ray generator was equipped with a $2 \mathrm{~mm}$ diameter collimator and was powered with an accelerating potential difference of $35 \mathrm{kV}$ and an electronic current of $15 \mu \mathrm{A}$. For each sample, three measures were obtained, with an acquisition time of $200 \mathrm{~s}$ each.

SEM investigation on cross section from rim to core of samples was performed using a FEI-Quanta 400 (SEM-EDS) instrument, operating at $30 \mathrm{kV}$, equipped with X-ray energy-dispersive spectroscopy (Department of Earth Sciences, Sapienza University of Rome, Italy). X-ray maps and SE/BSE imaging were carried out to investigate microstructure of the alloy, to estimate the depth of the corrosion and the elemental distribution from the external rim to core.

EMPA data for quantitative chemical analyses were performed using a Cameca SX50 electron microprobe equipped with five wavelength-dispersive spectrometers (CNR-IGAG, Rome, c/o Department of Earth Sciences, Sapienza University of Rome). The operating conditions were: accelerating voltage $15 \mathrm{kV}$, beam current $15 \mathrm{nA}$. Element peaks and background were measured with counting times of 20 and 10 s respectively. Metallic $\mathrm{Cu}$ and metallic $\mathrm{Zn}$ were used respectively as a reference standard for $\mathrm{Cu}$ and $\mathrm{Zn}$ (LIF), galena for $\mathrm{Pb}$ (PET), cassiterite for $\mathrm{Sn}$ (PET), metallic Ni and metallic Co respectively for Ni and Co (LIF), synthetic GaAs for As (TAP), rhodonite and metallic Mn for Mn (PET), olivine and synthetic magnetite for Fe (LIF). Matrix corrections were calculated by the PAP method ${ }^{52}$, with software supplied by Microbeams Services. The detection limits under the specified working condition vary from 0.05 to $0.1 \mathrm{wt} \%$ with standard deviations from 0.02 to $0.04 \mathrm{wt} \%$. The analytical error was $\sim 1 \%$ rel. for the major elements.

\section{References}

1. Craddock, P. T. The composition of the copper alloys used by the Greek, Etruscan and Roman civilizations. Journal of Archaeological Science 5, 1-16 (1978).

2. Caley, E. R. Orichalcum and related ancient alloys. (American Numismatic Society, 1964).

3. Caponetti, E. et al. First discovery of orichalcum ingots from the remains of a 6th century BC shipwreck near gela (Sicily) seabed. Mediterranean Archaeology and Archaeometry 17, 11-18 (2017).

4. Martini, C. et al. Investigations on a brass armour: Authentic or forgery? Materials Chemistry and Physics 142, 229-237 (2013).

5. Ashkenazi, D., Taxel, I. \& Tal, O. Archeometallurgical characterization of Late Roman- and Byzantine-period Samaritan magical objects and jewelry made of copper alloys. Materials Characterization 102, 195-208 (2015).

6. Barrena, M. I., Gómez de Salazar, J. M. \& Soria, A. Corrosion of brass archaeological blinker: Characterisation of natural degradation process. Materials Letters 62, 3944-3946 (2008).

7. Ashkenazi, D., Inberg, A., Langgut, D., Hendler, N. \& Cvikel, D. Brass-iron couple and brass-iron-wood ternary system of metal objects from the Akko 1 shipwreck (Israel). Corrosion Science 110, 228-241 (2016).

8. Smekalova, T. N. The earliest application of brass and 'pure' copper in the Hellenistic coinages of Asia Minor and the northern Black Sea coast. Mithridates VI and the Pontic Kingdom 233-48 (2009).

9. Amela Valverde, L. RRC 476 y 550, dos emisiones en oricalco de C. Julio César. Nvmisma 248, 7-22 (2004).

10. Catalli, F. Numismatica greca e romana. (Istituto Poligrafico e Zecca dello Stato, 2003).

11. Bourgarit, D. \& Bauchau, F. The ancient brass cementation processes revisited by extensive experimental simulation. JOM 62, 27-33 (2010).

12. Bayley, J. The production of brass in antiquity with particular reference to Roman Britain. In 2000 Years of zinc and brass 50, (P. T. Craddock, 1998)

13. Rehren, T. Small Size, Large Scale Roman Brass Production in Germania Inferior. Journal of Archaeological Science 26, $1083-1087$ (1999).

14. Bayley, J. \& Rehren, T. Towards a functional and typological classification of crucibles. In Metals and Mines: Studies in Archaeometallurgy (La Niece, Susan; Hook, Duncan R.; Craddock, P. T., 2007). 
15. Craddock, P. T., Freestone, I., Gurjar, L., Middleton, A. \& Willies, L. Zinc in India. In 2000 Years of zinc and brass 50, (P. T. Craddock, 1998).

16. Zhou, W., Martinón-Torres, M., Chen, J. \& Li, Y. Not so efficient, but still distilled: the technology of Qing Dynasty zinc production at Dafengmen, Chongqing, southwest China. Journal of Archaeological Science 43, 278-288 (2014).

17. Luo, W., Li, D., Mu, D., Bai, J. \& Xiao, B. Preliminary study on zinc smelting relics from the Linjiangerdui site in Zhongxian County, Chongqing City, southwest China. Microchemical Journal 127, 133-141 (2016).

18. Dungworth, D. Roman Copper Alloys: Analysis of Artefacts from Northern Britain. Journal of Archaeological Science 24, 901-910 (1997).

19. Papadopoulou, O., Vassiliou, P., Grassini, S., Angelini, E. \& Gouda, V. Soil-induced corrosion of ancient Roman brass - A case study. Materials and Corrosion 67, 160-169 (2016).

20. Chiavari, C. et al. Atmospheric corrosion of fire-gilded bronze: corrosion and corrosion protection during accelerated ageing tests. Corrosion Science 100, 435-447 (2015).

21. Marshakov, I. K. Corrosion Resistance and Dezincing of Brasses. Protection of Metals 41, 205-210 (2005).

22. Campanella, L., Colacicchi Alessandri, O., Ferretti, M. \& Plattner, S. H. The effect of tin on dezincification of archaeological copper alloys. Corrosion Science 51, 2183-2191 (2009).

23. Mattsson, E. Corrosion of Copper and Brass: Practical Experience in relation to Basic Data. British Corrosion Journal 15, 6-13 (1980).

24. Corsi, J. et al. Compositional and microstructural characterization of Celtic silver coins from northern Italy using neutron diffraction analysis. Microchemical Journal 126, 501-508 (2016).

25. Doménech-Carbó, M. T. et al. FIB-FESEM and EMPA results on Antoninianus silver coins for manufacturing and corrosion processes. Scientific Reports 8, 10676 (2018).

26. Calliari, I., Magrini, M., Zambon, A., Guerriero, P. \& Martini, R. Microstructural and compositional characterization of Roman coins. X-Ray Spectrom. 28, 86-90 (1999).

27. Giumlia-Mair, A. On surface analysis and archaeometallurgy. Nuclear Instruments and Methods in Physics Research Section B: Beam Interactions with Materials and Atoms 239, 35-43 (2005).

28. Scuotto, M. et al. X-ray fluorescence analysis on a group of coins from the ancient roman city of Tridentum (Trento, Italy). X-Ray Spectrom. 43, 370-374 (2014).

29. Di Fazio, M. et al. New insights on medieval Provisini silver coins by a combination of non-destructive and micro-invasive techniques. Microchemical Journal 144, 309-318 (2019).

30. Fabrizi, L. et al. The application of non-destructive techniques for the study of corrosion patinas of ten Roman silver coins: The case of the medieval Grosso Romanino. Microchemical Journal 145, 419-427 (2019).

31. Ospitali, F., Chiavari, C., Bernardi, E., Passarini, F. \& Robbiola, L. The characterization of Sn-based corrosion products in ancient bronzes: a Raman approach. J. Raman Spectrosc. 43, 1596-1603 (2012).

32. Mezzi, A. et al. Combined use of SA-XPS, XRD and SEM + EDS for the micro-chemical characterisation of Ag-based archaeological artefacts. Surf. Interface Anal. 46, 801-806 (2014).

33. Ager, F. J. et al. Silver surface enrichment in ancient coins studied by micro-PIXE. Nuclear Instruments and Methods in Physics Research Section B: Beam Interactions with Materials and Atoms 306, 241-244 (2013).

34. Di Turo, F. et al. Archaeometric analysis of Roman bronze coins from the Magna Mater temple using solid-state voltammetry and electrochemical impedance spectroscopy. Analytica Chimica Acta 955, 36-47 (2017).

35. Di Turo, F. et al. Dating Archaeological Strata in the Magna Mater Temple Using Solid-state Voltammetric Analysis of Leaded Bronze Coins. Electroanalysis 30, 361-370 (2018).

36. Doménech-Carbó, A., del Hoyo-Meléndez, J. M., Doménech-Carbó, M. T. \& Piquero-Cilla, J. Electrochemical analysis of the first Polish coins using voltammetry of immobilized particles. Microchemical Journal 130, 47-55 (2017).

37. Doménech-Carbó, A. et al. Electrochemical Characterization of Coinage Techniques the 17th Century: The maravedís Case. Electroanalysis 29, 2008-2018 (2017).

38. Cepriá, G., Aranda, C., Pérez-Arantegui, J., Lacueva, F. \& Castillo, J. R. Voltammetry of immobilised microparticles: a powerful analytical technique to study the physical and chemical composition of brass. Journal of Electroanalytical Chemistry 513, 52-58 (2001).

39. Di Turo, F., Parra, R., Piquero-Cilla, J., Favero, G. \& Doménech-Carbó, A. Crossing VIMP and EIS for studying heterogeneous sets of copper/bronze coins. Journal of Solid State Electrochemistry, https://doi.org/10.1007/s10008-018-04182-5 (2018).

40. Vadrucci, M. et al. Analysis of Roman Imperial coins by combined PIXE, HE-PIXE and $\mu$-XRF. Applied Radiation and Isotopes 143, $35-40$ (2019).

41. Crawford, M. H. Roman Republican Coinage. (Cambridge University Press, 1974).

42. Sutherland, C. H. V. The Roman Imperial Coinage: From 31 BC to AD 69: with introd. to the mints. (Spink, 1984).

43. Barello, F. Archeologia della moneta: produzione e utilizzo nellantichità. (Carocci, 2006).

44. Scott, D. A. Metallography and microstructure of ancient and historic metals. (Getty Conservation Institute in association with Archetype Books, 1991)

45. Giardino, C. I metalli nel mondo antico. Introduzione allarcheometallurgia. (Editori Laterza, 1998).

46. Sieradzki, K., Kim, J. S., Cole, A. T. \& Newman, R. C. The Relationship Between Dealloying and Transgranular Stress-Corrosion Cracking of $\mathrm{Cu}-\mathrm{Zn}$ and Cu-Al Alloys. Journal of The Electrochemical Society 134, 1635-1639 (1987).

47. Constantinides, I., Adriaens, A. \& Adams, F. Surface characterization of artificial corrosion layers on copper alloy reference materials. Applied Surface Science 189, 90-101 (2002).

48. Carter, G. F., Kimiatek, M. H., Klupacs, F. J. \& Giard, J.-B. Chemical Compositions of Copper-Based Roman Coins. V. Imitations of Caligula, Claudius and Nero. Revue numismatique 69-88 (1978).

49. Boni, M., Gilg, H. A., Aversa, G. \& Balassone, G. The 'Calamine’ of Southwest Sardinia: Geology, Mineralogy, and Stable Isotope Geochemistry of Supergene Zn Mineralization. Economic Geology 98, 731 (2003).

50. Alfantazi, A. M., Ahmed, T. M. \& Tromans, D. Corrosion behavior of copper alloys in chloride media. Materials \& Design 30, 2425-2430 (2009).

51. Caley, E. R. On the existence of chronological variations in the composition of Roman brass. The Ohio journal of science 55, 137-140 (1955).

52. Pouchou, J. \& Pichior, F. PAP f(rZ) procedure for improved quantitative analysis. In Microbeam analysis 3, 104-106 (Armstrong, J. T. (Ed.), 1985).

\section{Acknowledgements}

Financial support was provided by Sapienza University of Rome (Ateneo funding, 2016-17) and Ministero dell'Istruzione, dell'Università e della Ricerca (funding FFABR 2017). PhD grants of the Department of Earth Sciences, Sapienza University of Rome, are gratefully acknowledged. The authors are indebted to Private Collectors for generously providing the coins which were sacrificed for the study. 


\section{Author Contributions}

A.C.F. and M.D. acquired and interpreted the XRF data. F.C. obtained the coins here studied from different collection from Private Collectors and wrote the historical context. M.D. and C.D. designed the study and planned the experiments, acquired and interpreted SEM and EMPA data and wrote the manuscripts with the contribution of the other authors.

\section{Additional Information}

Supplementary information accompanies this paper at https://doi.org/10.1038/s41598-019-48941-4.

Competing Interests: The authors declare no competing interests.

Publisher's note: Springer Nature remains neutral with regard to jurisdictional claims in published maps and institutional affiliations.

(c) (i) Open Access This article is licensed under a Creative Commons Attribution 4.0 International License, which permits use, sharing, adaptation, distribution and reproduction in any medium or format, as long as you give appropriate credit to the original author(s) and the source, provide a link to the Creative Commons license, and indicate if changes were made. The images or other third party material in this article are included in the article's Creative Commons license, unless indicated otherwise in a credit line to the material. If material is not included in the article's Creative Commons license and your intended use is not permitted by statutory regulation or exceeds the permitted use, you will need to obtain permission directly from the copyright holder. To view a copy of this license, visit http://creativecommons.org/licenses/by/4.0/.

(C) The Author(s) 2019 